\title{
Heregulin, a new regulator of telomere length in human cells
}

\author{
Javier A. Menendez ${ }^{1,2, *}$, Miguel A. Rubio ${ }^{3, *}$, Judith Campisi ${ }^{4,5}$ and Ruth Lupu ${ }^{6,7}$ \\ 1 ProCURE (Program Against Cancer Therapeutic Resistance), Metabolism \& Cancer Group, Catalan Institute of Oncology \\ (ICO), Girona, Spain \\ ${ }^{2}$ Girona Biomedical Research Institute (IDIBGI), Girona, Spain \\ ${ }^{3}$ Laboratory of Hematology Service, Institut d'Investigació Biomèdica Sant Pau, Hospital de la Santa Creu i Sant Pau, \\ Barcelona, Spain \\ ${ }^{4}$ Lawrence Berkeley National Laboratory, Life Sciences Division, Berkeley, CA, USA \\ ${ }^{5}$ Buck Institute for Research on Aging, Novato, CA, USA \\ ${ }^{6}$ Mayo Clinic, Department of Laboratory Medicine and Pathology, Division of Experimental Pathology, Rochester, MN, USA \\ ${ }^{7}$ Mayo Clinic Cancer Center, Rochester, MN, USA \\ * These authors have contributed equally \\ Correspondence to: Ruth Lupu, email: lupu.ruth@mayo.edu
}

Judith Campisi, email: jmenendez@iconcologia.net

Keywords: heregulin, telomere, TRF2, RAP1, cancer, aging

Received: June 27, $2015 \quad$ Accepted: July 12, $2015 \quad$ Published: July 22, 2015

This is an open-access article distributed under the terms of the Creative Commons Attribution License, which permits unrestricted use, distribution, and reproduction in any medium, provided the original author and source are credited.

\section{ABSTRACT}

The growth factor heregulin (HRG) promotes breast cancer (BC) tumorigenesis and metastasis and differentially modulates BC cell responses to DNA-damaging agents via its dual extracellular and nuclear localization. Given the central role of telomere dysfunction to drive carcinogenesis and to alter the chemotherapeutic profile of transformed cells, we hypothesized that an unanticipated nuclear function of HRG might be to regulate telomere length. Engineered overexpression of the HRG $\beta 2$ isoform in non-aggressive, HRG-negative MCF-7 BC cells resulted in a significant shortening of telomeres (up to $1.3 \mathrm{~kb}$ ) as measured by Southern blotting of telomere terminal restriction fragments. Conversely, antisense-mediated suppression of HRG $\beta 2$ in highly aggressive, HRG-overexpressing MDA-MB-231 and Hs578T cells increased telomere length up to $3.0 \mathrm{~kb}$. HRG $\beta 2$ overexpression promoted a marked upregulation of telomere-binding protein 2 (TRF2) protein expression, whereas its knockdown profoundly decreased TRF2 expression. Double staining of endogenous HRG 32 with telomere-specific peptide nucleic acid probe/fluorescence in situ hybridization (PNA/ FISH) revealed the partial localization of HRG at the chromosome ends. Moreover, a predominantly nucleoplasmic staining pattern of endogenous HRG $\beta 2$ appeared to colocalize with TRF2 and, concomitantly with RAP1, a telomere regulator that specifically interacts with TRF2. Small interfering RNA-mediated knockdown of HRG decreased the expression of TRF 2 and RAP1, decreased their presence at chromosome ends, and coincidentally resulted in the formation of longer telomeres. This study uncovers a new function for HRG $\beta 2$ in controlling telomere length, in part due to its ability to regulate and interact with the telomere-associated proteins TRF2 and RAP1.

\section{INTRODUCTION}

The isoform $\beta 2$ of the heregulin (HRG) family of growth factors (HRG $\beta 2$ ) is a tumor-promoting growth factor conventionally described as an indirect activator of HER2 (erbB2) oncogene-driven signaling via its ability to bind HER3 (erbB3) and HER4 (erbB4) [1-8]. Our previous work showed that expression of HRG 32 cDNA in estrogen-dependent MCF-7 BC cells is sufficient to promote the loss of estrogen dependence and the acquisition of resistance to anti-estrogens [9], two phenotypic features closely related to the malignant 
progression of BC. Indeed, HRG $\beta 2$ promotes the in vivo progression from an estrogen-dependent, antiestrogensensitive and non-metastatic phenotype to an estrogenindependent, antiestrogen-resistant and metastatic phenotype [9, 10]. Stable suppression of HRG $\beta 2$ in HER2-negative metastatic BC cells efficiently abrogates their intrinsically aggressive behavior by inhibiting cell proliferation, preventing anchorage-independent growth and reducing their invasive potential in vitro [11]. Moreover, HRG $\beta 2$ blockade is accompanied by a marked reduction in tumor formation, tumor size, and an absence of metastasis in vivo [11], thus confirming the ability of HRG $\beta 2$ to drive carcinogenesis independently of HER2.

HRG $\beta 2$ differentially modulates BC cell sensitivity to DNA-damaging agents [12-14]. Forced expression of HRG $\beta 2$ promotes hypersensitization of $\mathrm{BC}$ cells to doxorubicin (DOX), an inducer of DNA double-strand breaks (DSB). Conversely, HRG $\beta 2$ overexpression confers resistance to the alkylating agent cisplatin (CDDP). Because overexpression and hyperactivation of HER2 determines also the sensitivity profile of cancer cells to DNA-damaging drugs $[15,16]$, it could be contended that HRG $\beta 2$-driven $\mathrm{BC}$ chemosensitivity merely reflects an ability of HRG $\beta 2$ to activate HER2. Our previous studies, however, showed that the tumorigenic properties of HRG $\beta 2$, which depend largely on its ability to activate the HER2-/-3/-4 network, could be dissociated from its regulatory effects on chemosensitivity to DNA-damaging agents. Accordingly, a non-tumorigenic structural mutant of HRG $\beta 2$ lacking N-terminal sequences and the cytoplasmic domain was sufficient to enhance BC cell sensitivity to DOX while abolishing resistance to CDDP [13].

An attractive molecular candidate to explain the paradoxical effects of HRG $\beta 2$ on carcinogenesis and chemosensitivity is the telomere, and more specifically, its end-capping function. On the one hand, telomere length stability is one of the key factors contributing to the proliferative capacity of many cancer cell types; consequently, depending on their length and functional state, telomeres serve to suppress or promote malignant transformation [17-19]. On the other hand, the inhibition of telomere maintenance acts to chemosensitize cancer cells to DSB inducers (e.g., doxorubicin), whereas long telomeres are good targets for drugs targeting the G-rich telomeric sequence (e.g., cisplatin). Accordingly, telomere dysfunction has been shown to be a central molecular determinant governing the chemosensitivity of cancer cells to agents that induces DSBs including DOX [20, 21], while massive telomere shortening and degradation is an early event of CDDP-induced apoptosis [22, 23].

HRG $\beta 2$ has been demonstrated to exhibit a dual cellular localization. It can be secreted into the intercellular space of the epithelium, where it performs its well-characterized paracrine or autocrine functions, and it can also translocate to the nucleus in cancer cells [13,
$24,25]$. It remains unclear, however, which functions are exclusively dependent on the activation of HER receptors and which are exclusively attributed to nuclear HRG $\beta 2$. Here we hypothesized that the nuclear localization of HRG $\beta 2$ might relate to its ability to regulate telomere length and function in human cancer cells. We report for the first time that HRG $\beta 2$ is a previously unrecognized modulator of telomere length maintenance through its ability to regulate telomere-associated proteins, and plays an essential role in protecting telomere integrity at chromosome ends [26-35]. The discovery of HRG $\beta 2$ as a new regulator of telomere length suggests that the tumorigenic and metastatic functions of HRG $\beta 2$ might be explained in terms of its nuclear occupation as a novel interactor of the telosome/shelterin complex in human telomeres.

\section{RESULTS}

\section{HRGß2 overexpression promotes telomere shortening in breast cancer cells}

To study the effects of HRG $\beta 2$ forced expression on telomere length, we employed a BC progression model previously developed in our laboratory in which full length HRG $\beta 2$ cDNA is transfected into non-metastatic MCF-7 BC cells [9]. We used Southern blotting to evaluate the length of the terminal restriction fragments (TRF) in two representative HRG $\beta 2$-overexpressing MCF-7 clones (T6 and T8) and in control, empty vector cells. Although it is acknowledged that TRF length and telomere length are not the same measurements (telomere length is a measure of the terminal TTAGGG tract, whereas TRF reflects telomeres and adjacent sub-telomeric regions), TRF analysis can be used to determine the mean length of the terminal TTAGGG tract or the mean telomere length by measuring both the rate of decrease of mean TRF length and telomeric signal intensity as a function of population doubling [36, 37]. Using this measurement, we found that the average TRF length was significantly shortened from $3.4 \pm 0.2 \mathrm{~kb}$ in empty vector-transfected MCF-7 cells $(\mathrm{MCF}-7 / \mathrm{V})$, to $2.4 \pm 0.1$ and $2.2 \pm 0.1 \mathrm{~kb}$ in T6 and $\mathrm{T} 8$ clones, respectively (Figure 1A, left panel). No major changes in telomere length were observed over many ensuing population doublings

\section{Antisense inhibition of HRG $\beta 2$ promotes telomere lengthening in breast cancer cells}

To validate the above findings, we utilized a cancer cell line that naturally overexpresses HRG $\beta 2$, and stably transfected an antisense (AS) HRG $\beta 2$ construct [11]. Two representative AS-HRG $\beta 2$ clones of the MDA-MB-231 human BC cell line (MDA-MB-231/AS-31 and MDA- 

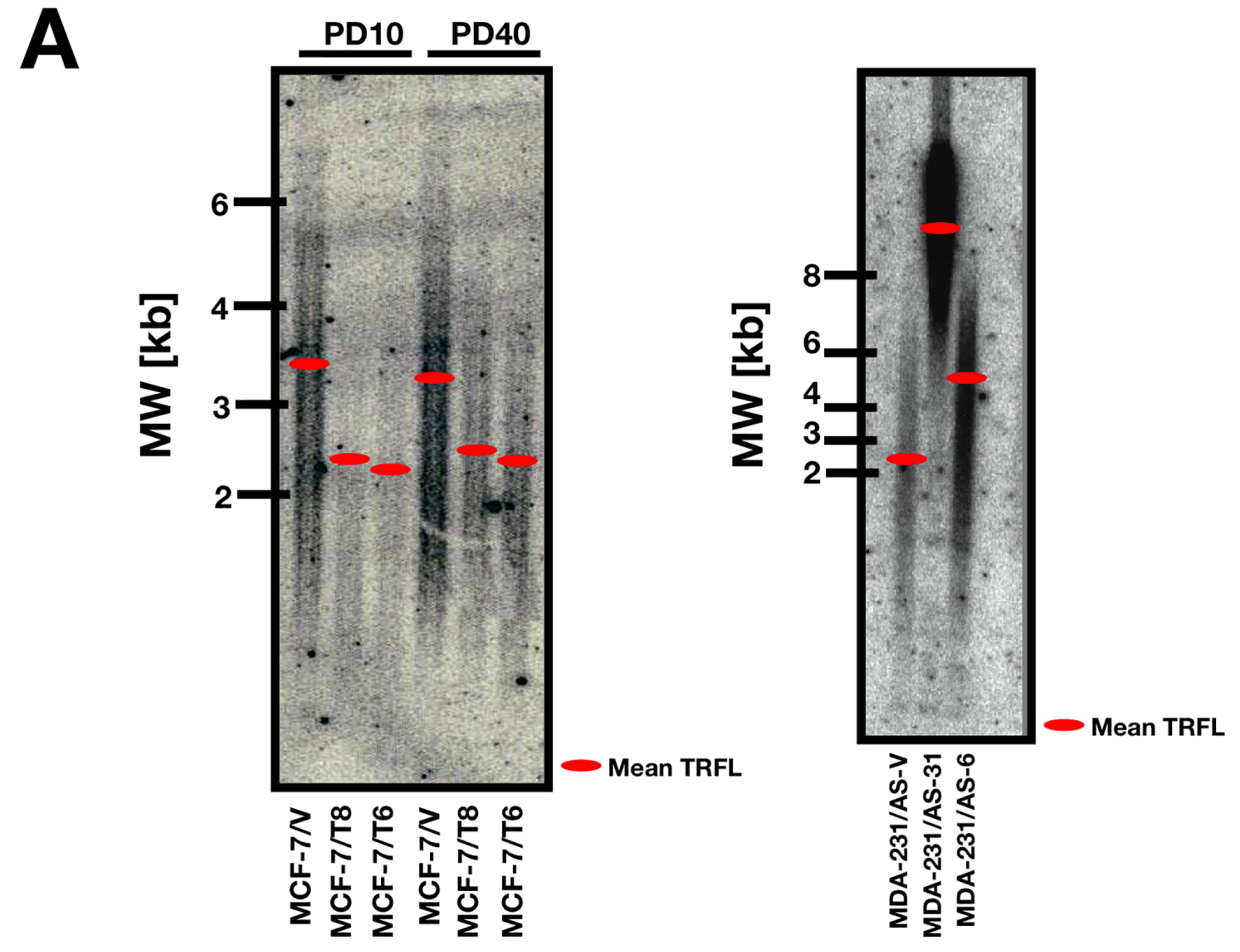

B

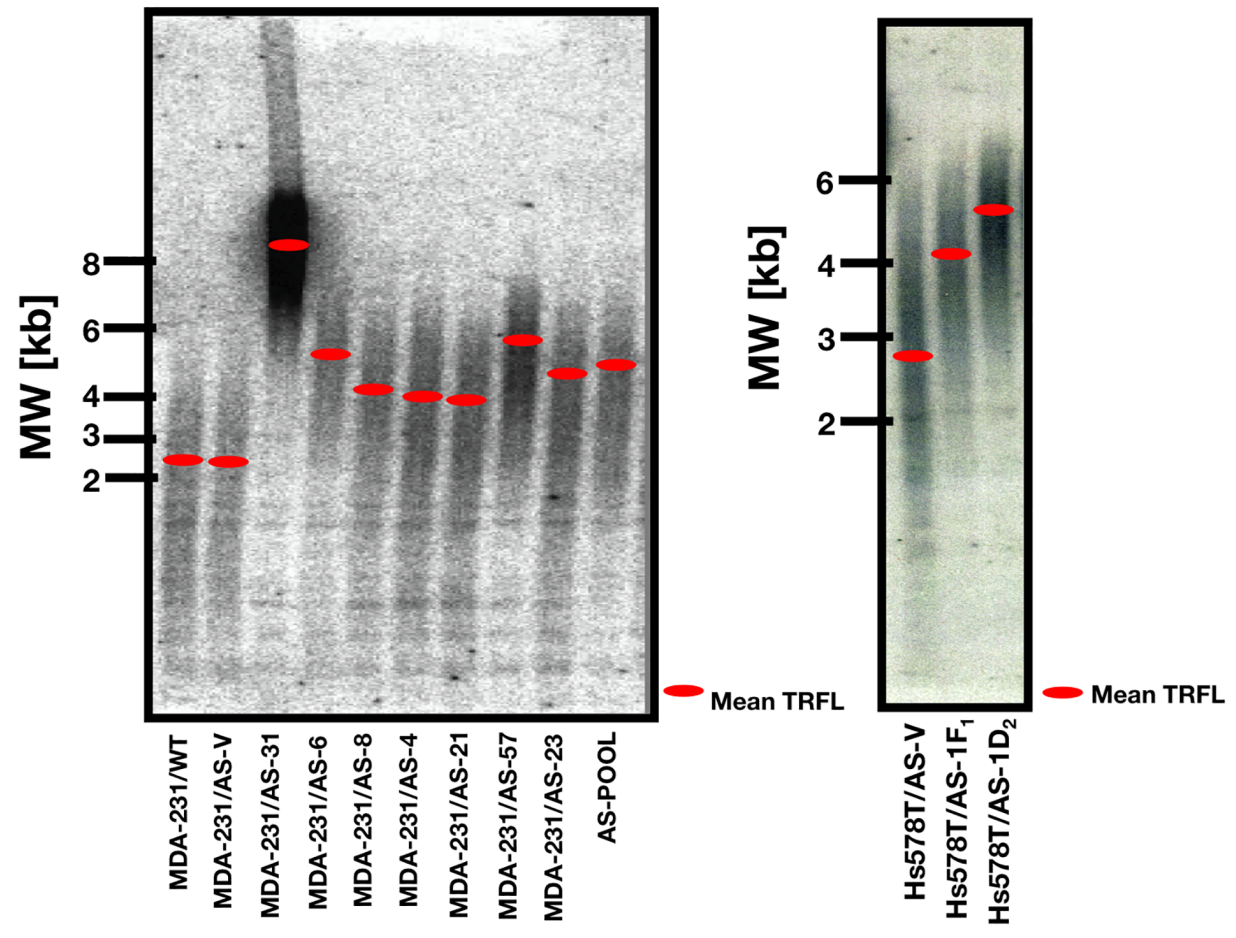

Figure 1: HRGß2 regulates telomere length in human breast cancer cells. A., B. DNA from MCF-7 cells engineered to stably overexpress full-length human HRG $\beta_{2}$ cDNA (MCF-7/T clones) and equivalent empty-vector (MCF-7/V control cells), and DNA from HRG $\beta_{2}$-overexpressing MDA-MB-231 and Hs578T cells and equivalent antisense AS-HRG $\beta_{2}$ cells was isolated from collected cell pellets with inclusion of an RNase-A digestion step. Genomic DNA was digested with HinfI/RsaI, and genomic blotting for telomeric fragments was carried out according to standard protocols (see "Materials and Methods" section for details). In-gel hybridization was performed using an end-labeled (TTAGGG) ${ }_{3}$ probe following in situ denaturation of the DNA. Telomere gels were exposed to a Phosphorimager screen for $24 \mathrm{~h}$ and signals were quantified using ImageQuant software. Red bars indicate the median size of telomere length. The numbers on the left show the positions of a DNA-sizing ladder (in kb). 
MB-231/AS-6) exhibited marked differences in telomere length compared with vector control, as assessed by genomic blotting (Figure 1A, right panel). We previously demonstrated that, when the HRG $\beta 2$ protein expression was determined by Western blot analysis using an anti-HRG rabbit polyclonal antibody generated in our laboratory [9], the expression of HRG $\beta 2$ was significantly reduced by 25-30-fold in the AS-6 cells and it becomes almost undetectable in AS-31 cells as compared to empty vector-transfected MDA-MB-231 cells (AS-V) [11]. Average TRF length was significantly lengthened from $2.4 \pm 0.2 \mathrm{~kb}$ in MDA-MB-231/AS-V cells, to $5.5 \pm 0.2$ $\mathrm{kb}$ in MDA-MB-231/AS-6 cells. Notably, telomeres in MDA-MB-231/AS-31 cells were considerably lengthened $(8.6 \pm 0.5 \mathrm{~kb})$, i.e., $6.2 \mathrm{~kb}$ longer than the mean telomere length in control cells. The mean TRF length in AS-6 and AS-31 clones did not vary over many ensuing population doublings.

To exclude the possibility that these observations were clone-specific, TRF length was evaluated in a wider panel of AS-HRG $\beta 2$ and MDA-MB-231 clones. The TRF length of control cells (MDA-MB-231/WT and MDA-MB-231/AS-V), seven single-clone ASHRG 32 transfectants (AS-31, AS-4, AS-6, AS-8, AS21, AS-57, and AS-23), and an AS-HRGß2-transfected pooled population (AS-POOL) are shown in Figure 1B (left panel). A significant increase in telomere length was observed in all single-clone AS-HRG $\beta 2$ derivatives (mean TRF length $=5.2 \mathrm{~kb}$; range $3.9-8.6 \mathrm{~kb}$ ) as well as in the AS-POOL population (TRF length $=5.0 \pm 0.2 \mathrm{~kb}$ ). Similar results were obtained in AS-HRG $\beta 2$ clones from the highly metastatic and HRG $\beta 2$-overexpressing Hs578T human BC cell line (Figure 1B, right panel). Accordingly, AS-HRG 32 Hs578T transfectants showed a significant increase in TRF length, from $2.8 \pm 0.1 \mathrm{~kb}$ in empty vector-

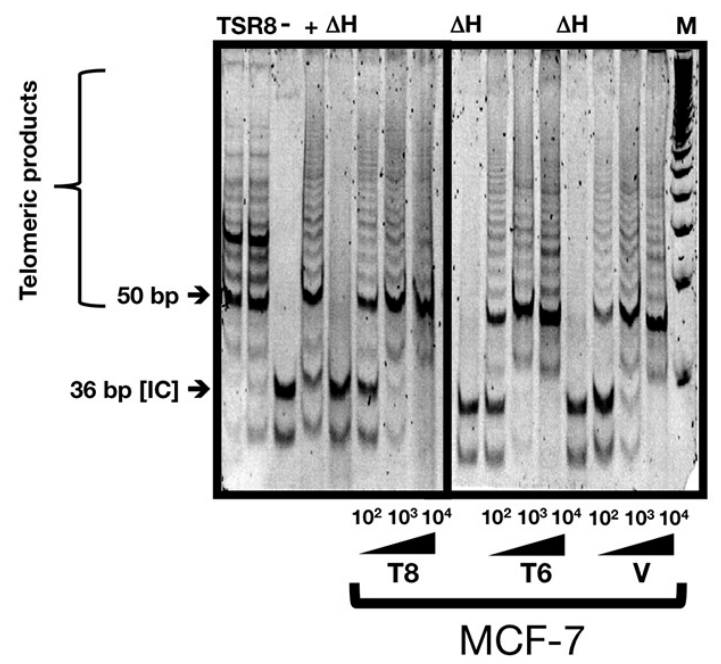

transfected Hs578T (AS-V), to $4.2 \pm 0.2$ and $5.3 \pm 0.2 \mathrm{~kb}$ in the $1 \mathrm{~F}_{1}$ and $1 \mathrm{D}_{2} \mathrm{AS}-\mathrm{HRG} \beta 2$ clones, respectively.

\section{HRG $\beta 2$ does not modulate telomerase activity in breast cancer cells}

Because telomere length is controlled by a homeostatic mechanism that involves telomerase and several telomeric proteins, it was important to determine whether HRG $\beta 2$-related changes in telomere length reflected changes in telomerase activity and/or telomere-binding protein expression. Using a sensitive semi-quantitative PCR-based assay (TRAP) to measure telomerase activity, we failed to detect significant changes in telomerase activity in HRG 32 -overexpressing MCF-7/ T6 and MCF-7/T8 clones when compared with MCF-7/V control cells as assessed by the intensity of telomerase products detected in the TRAP assay (Figure 2, left panel). Similarly, we found no significant differences in telomerase activity of AS-HRG $\beta 2$ MDA-MB-231/ AS-31 and MDA-MB-231/AS-6 clones when compared with MDA-MB-231/AS-V cells (Figure 2, right panel). Moreover, telomerase activity levels in Hs578T/AS-1F and Hs578T/AS-1D 2 clones did not differ when compared with Hs578T/AS-V cells (data not shown).

\section{HRG $\beta 2$ regulates TRF2 expression in breast cancer cells}

Although several proteins occupy the mammalian telomere and serve to regulate its structure, two closely related proteins TRF1 and TRF2 (telomere repeat binding factor 1 and 2), appear to be exclusively localized to the

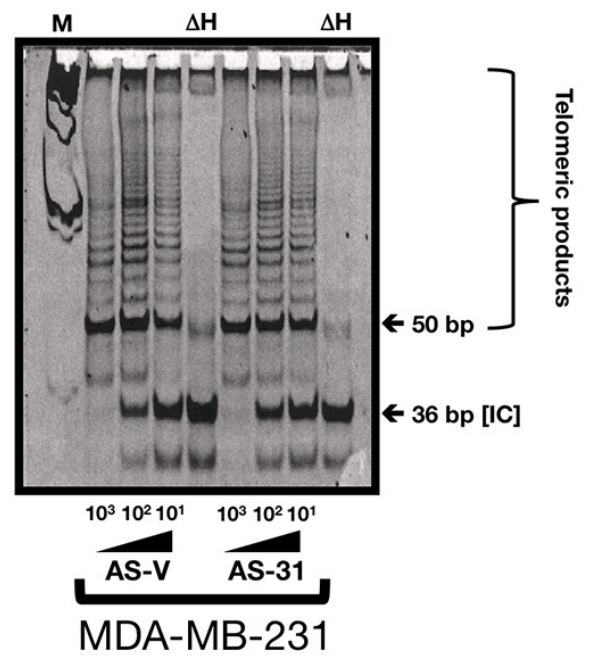

Figure 2: HRG 32 does not modify telomerase activity in breast cancer cells. Telomerase activity was assessed by the Telomere Repeat Amplification Protocol (TRAP) using a commercial kit. One to four thousand cell equivalents were used for each reaction with a representative experiment shown $(n=3)$. TSR8: Synthetic telomerase product. IC: Denotes the 36-bp internal control that serves to normalize sample-to-sample variation. M: Molecular weight markers. $\Delta \mathrm{H}$ : Heat-inactivated control. 
mammalian telomere $[26,28]$. TRF1 and TRF2 each bind double-stranded telomeric DNA as homodimers; TRF1 homodimers are postulated to monitor telomere length, while TRF2 homodimers serve to stabilize telomeric loop (t-loop) formation and protect telomere integrity. Immunoblotting of whole cell lysates from $\mathrm{BC}$ cells overexpressing HRG $\beta 2$ (MCF-7/T clones) using specific antibodies against TRF1 and TRF2 revealed that whereas TRF1 expression was unchanged relative to $\mathrm{MCF}-7 / \mathrm{V}$ control cells, TRF2 expression was markedly increased (Figure 3A). Indeed, expression levels of the 65/69 kb TRF2 doublet were significantly greater in HRG $\beta 2$ overexpressing cells regardless of whether the cells were actively cycling or growth arrested by serum starvation (Figure 3B).

When we compared TRF2 expression in ASHRG $\beta 2$ clones with that found in naturally HRG $\beta 2$ overexpressing MDA-MB-231 and Hs578T cell lines, we observed a negative correlation between TRF2 expression and telomere length in AS-HRG $\beta 2$ MDAMB-231 transfectants (Figure 3C, left panel and Figure 1B). Thus, MDA-MB-231/AS-HRG $\beta 2$ clones with longer telomeres had lower levels of endogenous TRF2 (e.g., AS-31, AS-6, and AS-57 clones in Figure 3C), whereas MDA-MB-231/AS-HRG $\beta 2$ clones with shorter telomeres had higher levels of endogenous TRF2 (e.g., AS-4 and AS-21 clones in Figure 3C). Moreover, TRF2 protein expression was dramatically reduced upon AS-driven blockade of HRG 32 expression in Hs578T cells (Figure $3 \mathrm{C}$, right panel). Indeed, we found TRF2 levels to be at least $90 \%$ lower in Hs578T/AS-1F ${ }_{1}$ and Hs $578 \mathrm{~T} / \mathrm{AS}-1 \mathrm{D}_{2}$ clones relative to Hs578T/AS-V control cells (Figure 3C, right panel). Conversely, AS-driven down-regulation of HRG 32 expression in MDA-MB-231 and Hs578T cells did not significantly affect TRF1 expression (Figure 3C).

As a complementary approach, we examined TRF2 expression after exposure of cells to recombinant HRG. Exogenous addition of HRG to HRG $\beta 2$-negative MCF-7 cells induced a specific and dose-dependent upregulation of TRF2 without affecting TRF1 levels (Figure 3D, left panel). Furthermore, exogenous HRG supplementation could partially recover the extremely low levels of TRF2 induced by AS-driven blockade of endogenous HRG $\beta 2$ in the AS-HRG $\beta 2$ Hs578T derivatives $1 \mathrm{~F}_{1}$ and $1 \mathrm{D}_{2}$, (Figure $3 \mathrm{D}$, right panel).

We next determined whether HRG $\beta 2$-related changes in TRF2 protein expression correlated with changes in TRF2 transcript levels. Thus, we extracted total RNA from MCF-7 cells overexpressing HRG $\beta 2$ and also from AS-HRG $\beta 2$ MDA-MB-231 and Hs578T transfectants, and measured TRF2 mRNA by RT-PCR. Results showed that, contrary to the marked differences observed in TRF2 protein levels, TRF2 mRNA levels were relatively constant between the different cell types and no correlation was found with TRF2 protein levels (data not shown).

\section{HRG $\beta 2$ localizes at telomeres with the telomere- associated proteins TRF2 and RAP1}

Finally, to further evaluate a causal role of HRG $\beta 2$ in telomere homeostasis, we undertook a multi-step approach. First, to better determine the consequences of increased HRG $\beta 2$ expression for both telomere length dynamics and telomere-binding protein expression, we introduced additional copies of HRG $\beta 2$ into HRG $\beta 2$ negative MCF-7 BC cells to achieve levels more consistent with those found in tumor-derived human cell lines. Thus, HRG $\beta 2$ expression was driven by a retroviral LTR instead of the CMV promoter employed in the generation of the T6 and T8 clones, to assure a sustained high level of expression. Although MCF-7 cells, akin to other human tumor cell lines, can exhibit a high degree of variation in telomere length and dynamics, the analysis of large pools of retrovirally-infected cells is known to reduce outlier effects, thus allowing a more consistent assessment of the impact of ectopically overexpressed proteins on telomere length. By examining a pool of HRG $\beta 2$-infected cells subjected to puromycin selection, we found a significant upregulation of TRF2 and RAP1, a protein involved in the regulation of telomere structure, as early as PD 2 (Figure 4A, left panel), and these levels were sustained at late PD cultures. We failed to detect significant changes in telomerase activity between MCF-7/HRG $\beta 2$ cells and MCF-7/pBABE matched control cells by TRAP assay (Figure 4A, middle panel); however, the average TRF length was significantly shortened from $3.6 \pm 0.1 \mathrm{~kb}$ in empty vector-infected MCF-7/pBABE cells, to $2.2 \pm 0.1 \mathrm{~kb}$ in $\mathrm{MCF}-7 / \mathrm{HRG} \beta 2$ cells, as measured by Southern blotting (Figure 4A, right panel).

Having established that HRG $\beta 2$ can regulate TRF2 and RAP1 protein levels while concomitantly affecting telomere length maintenance, we next questioned whether HRG $\beta 2$ might modulate telomere homeostasis by forming a proteinaceous link with TRF2 and RAP1. To test this, we used siRNA transfection to deplete HRG $\beta 2$. Transfection of MDA-MB-231 cells with increasing concentrations of HRG-specific siRNA during $72 \mathrm{~h}$ resulted in a decrease of up to $70 \%$ of the baseline levels of HRG $\beta 2$ found in control (scramble siRNA) cells (Figure 4B). Of note, depletion of endogenous HRG $\beta 2$ diminished the abundance of TRF2 and RAP1 in a dose-dependent manner as assessed by immunoblotting. Further, immunocytochemistry confirmed a strong reduction in the telomeric signals of TRF2 and RAP1 upon HRG $\beta 2$ depletion since treatment with HRG-siRNA promoted an evident loss of the characteristic punctate pattern of TRF2 and RAP1 staining in $70 \%$ of the cells, and greater than $80 \%$ of the nuclei showed diminished TRF2 and RAP1 telomeric signals (Figure 4B).

Because a decrease in the accumulation of TRF2 and RAP1 upon HRG $\beta 2$ depletion might suggest that the stability and telomere-length regulatory functions of 
A

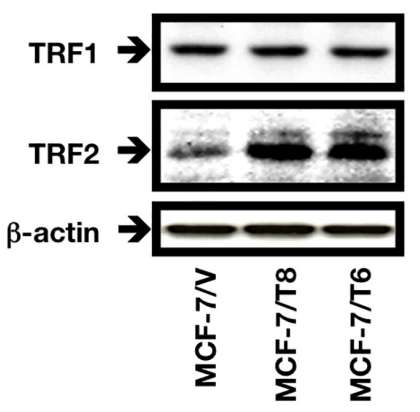

C

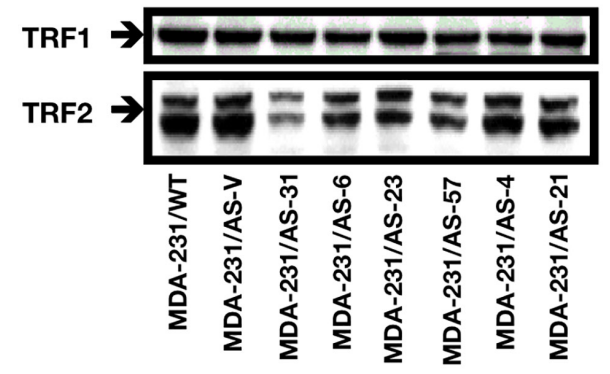

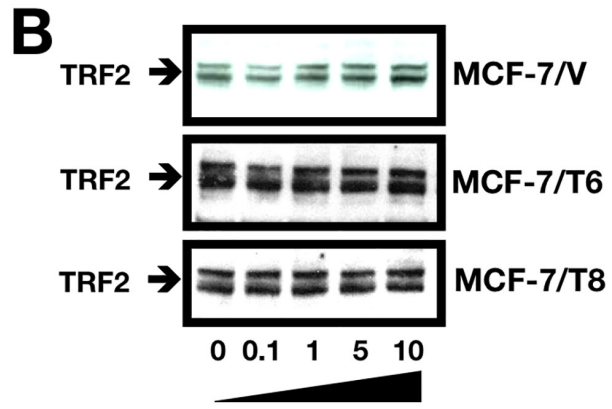

Serum (\%)

D
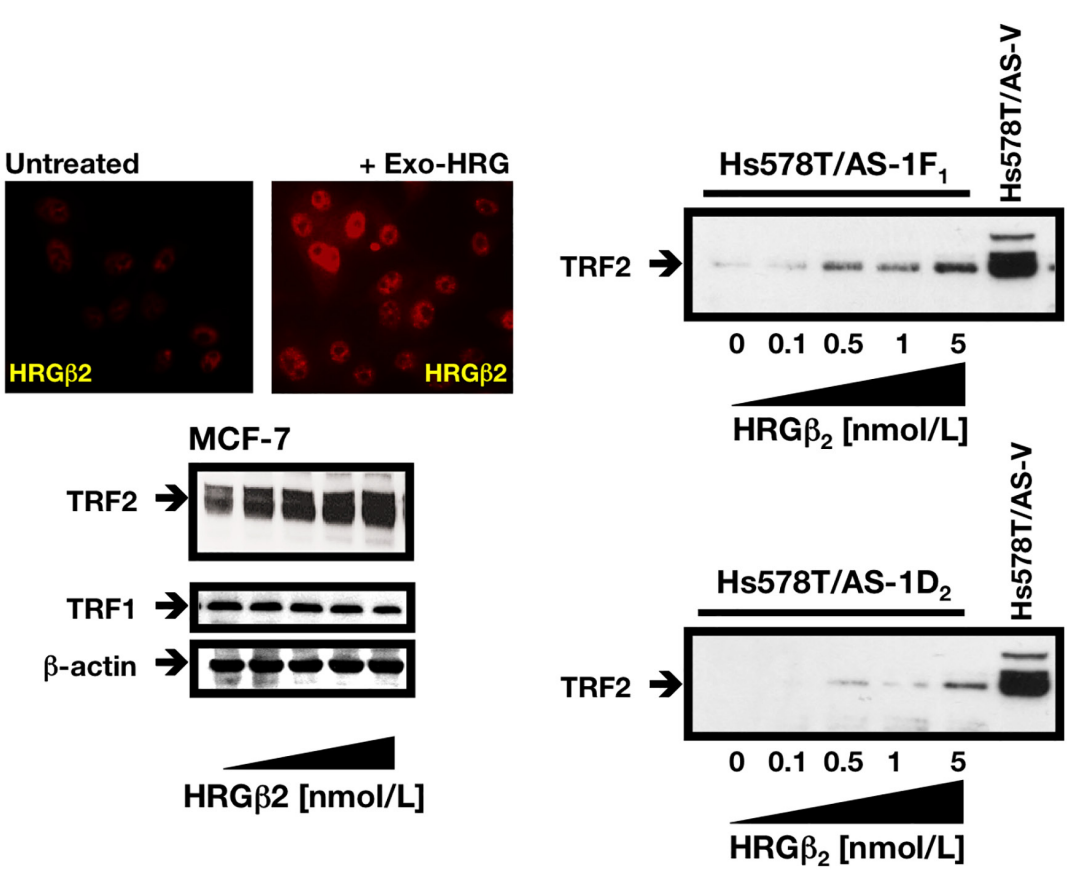

Figure 3: HRGß2 regulates TRF2 expression in breast cancer cells. A., B. Cells were washed with cold PBS and solubilized in lysis buffer containing phosphatase and protease inhibitors. Fifty $\mu \mathrm{g}$ of protein per sample was resolved by SDS-PAGE and subjected to Western blotting for TRF1 and TRF2. One representative immunoblot is shown $(n=3)$ [A: Asynchronous populations of MCF-7/V, MCF-7/T6 and MCF-7/T8 cells growing in regular medium; B: Overnight serum-starved (60-70\% confluence) MCF-7/V, MCF-7/T6 and MCF-7/T8 cells were cultured in the presence of increasing concentrations of FBS $(0 \%, 0.1 \%, 1 \%, 5 \%$ and $10 \%)$ for $48 \mathrm{~h}]$. C. Overnight serum-starved (75\% confluence) MDA-MB-231 (left) and Hs578T (right) cell lines and equivalent antisense AS-HRG $\beta_{2}$ derivatives were subjected to Western blotting for TRF1 and TRF2. One representative immunoblot is shown $(n=3)$. D. Overnight serum-starved $(75 \%$ confluence) MCF-7 (left) Hs578T/AS-1F1 and Hs578T/AS-1D2 cells (right) cells were treated with graded concentrations of recombinant HRG for $48 \mathrm{~h}$ in low-serum-medium (0.1\% FBS). Cells were then washed with cold PBS and solubilized in lysis buffer containing phosphatase and protease inhibitors. Fifty $\mu \mathrm{g}$ of protein per sample was resolved by SDS-PAGE and subjected to Western blotting for TRF2. One representative immunoblot is shown $(n=3)$. A representative immunofluorescent image of MCF-7 cells stained for HRG $\beta_{2}$ before and after exogenous treatment with recombinant HRG (red) is shown. 


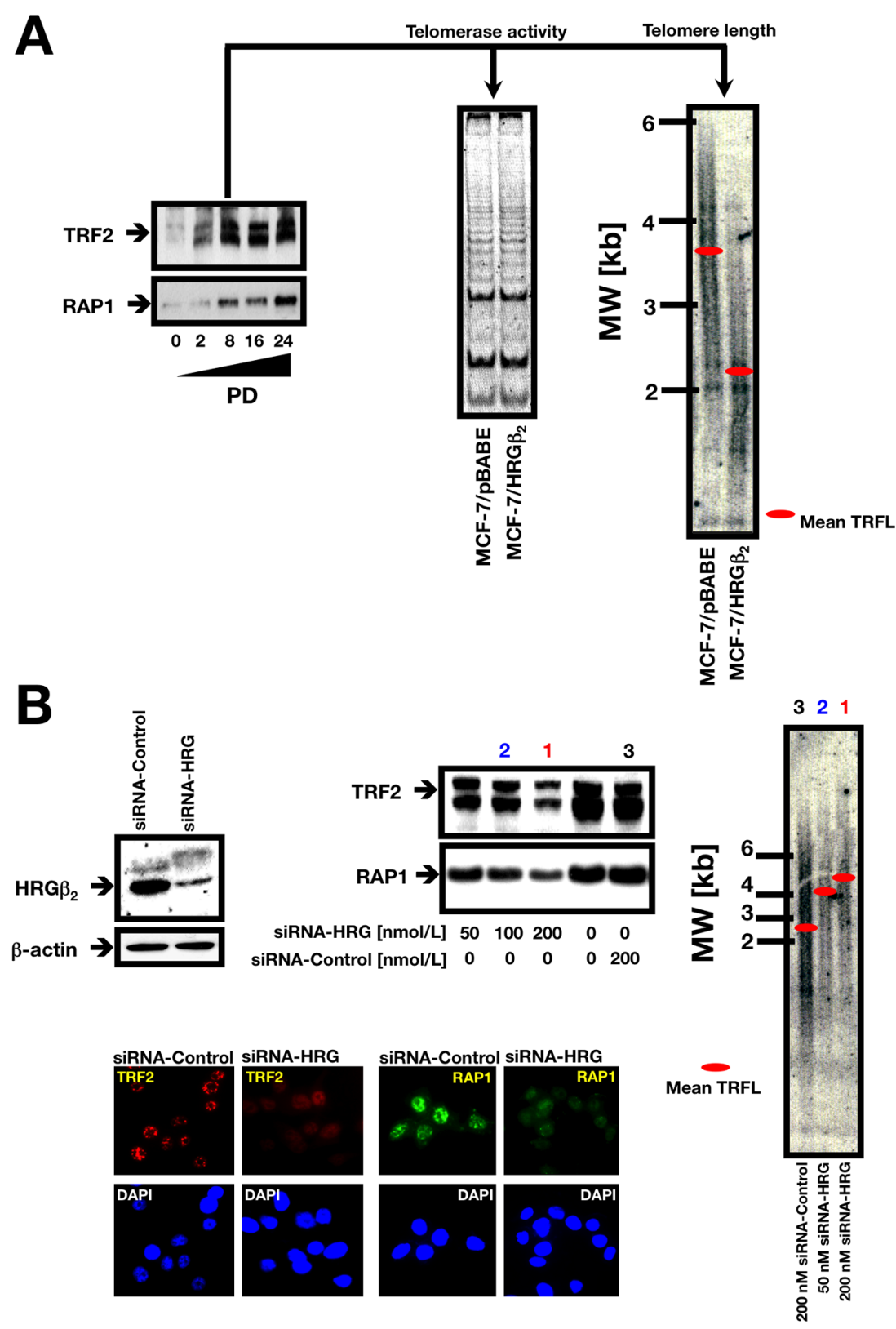

Figure 4: A. Retrovirally-induced HRG $\beta 2$ regulates TRF2 and RAP1 expression and telomere length in MCF-7 breast cancer cells. Left. Representative immunoblot $(n=3)$ showing upregulation of TRF2 and RAP1 in MCF-7 cells retrovirally engineered to overexpress HRG $\beta_{2}$. PD 0 represents the first sub-passage after selection for retroviral infection. At the indicated PDs, cells were washed with cold PBS and solubilized in lysis buffer containing phosphatase and protease inhibitors. Fifty $\mu \mathrm{g}$ of protein per sample was resolved by SDSPAGE and subjected to Western blotting for TRF2 and hRap1 as described above (see "Materials and Methods" for details). Middle panel. MCF-7/HRG $\beta_{2}$ cells do not exhibit significant changes in telomerase activity as assessed by the TRAP assay. Three thousand cell equivalents were used for each reaction and a representative experiment is shown $(n=3)$. Right panel. Telomere length changes in MCF-7 cells upon retrovirally-induced $\mathrm{HRG} \beta_{2}$ overexpression. The panel shows a representative genomic blotting analysis of telomeric restriction fragments in HinfI/RsaI-digested genomic DNA from retrovirally-infected MCF-7 cells probed with a TTAGGG repeat fragment. B. HRG knockdown reduces the presence of TRF2 and RAP1 on telomeres and promotes telomere lengthening. Top left. Depletion of HRG with siRNA significantly affects TRF2 and RAP1 protein levels. A representative Western blot of MDA-MB-231 cell lysates $72 \mathrm{~h}$ after transfection of siRNA to HRG or siRNA control is shown $(n=3)$. Top right. TRF length analysis in HRG knockdown MDA-MB-231 cells. The panel shows a representative genomic blotting analysis of telomeric restriction fragments in HinfI/RsaI-digested genomic DNA from MDA-MB-231 cells transiently transfected with control siRNA or graded concentrations of HRG siRNA (PD 4) probed with a TTAGGG repeat fragment $(n=3)$. Bottom. Reduced TRF2 and RAP1 telomeric signals after HRG siRNA treatment. Western blot analysis showing the significant depletion of $\mathrm{HRG} \beta_{2}$ protein with a specific siRNA. The panel shows representative immunofluorescence images of MDAMB-231 cells $48 \mathrm{~h}$ after introduction of HRG siRNA: staining with anti-TRF2 (red) and anti-RAP1 (green) antibodies is shown $(n=3)$. DAPI was used to visualize nuclear DNA (blue). 
TRF2 and RAP1 are linked to the presence of HRG $\beta 2$ at chromosome ends, we next assessed the possible changes in telomere length in HRG $\beta 2$ knockdown cells. We observed that siRNA knockdown of HRG $\beta 2$ was coincidental with a significant increase in telomere length, from $2.6 \pm 0.2 \mathrm{~kb}$ in MDA-MB-231 cells transfected with scramble control siRNA, to $5.1 \pm 0.2 \mathrm{~kb}$ in MDA-MB-231 cells transfected with $200 \mathrm{nmol} / \mathrm{L}$ of siRNA duplexes against HRG (Figure 4B). No significant changes in telomerase activity could be detected upon silencing of HRG $\beta 2$ expression in MDA-MB-231 cells (data not shown).

Lastly, we evaluated the sub-cellular distribution of endogenous HRG $\beta 2$ and its spatial relationship with telomeres and telomere-binding proteins TRF2 and RAP1. To study this issue, and to demonstrate further that the functional association between HRG $\beta 2$ expression and telomere homeostasis was not a specific feature of the $\mathrm{BC}$ models used for these experiments, we employed the A431 cell line, an independent in vitro human epidermoid metastatic cancer model naturally overexpressing HRG $\beta 2$. Indirect immunofluorescence studies with an anti-HRG $\beta 2$ antibody confirmed a predominant nuclear accumulation of endogenous HRG $\beta 2$ in A431 cells. Moreover, FISH analysis with a peptide nucleic acid (PNA)-telomere probe on cell metaphases previously stained for HRG $\beta 2$, showed that nuclear HRG $\beta 2$ was able to partially co-localize with PNA-stained duplexes (Figure 5). Also, immunostaining
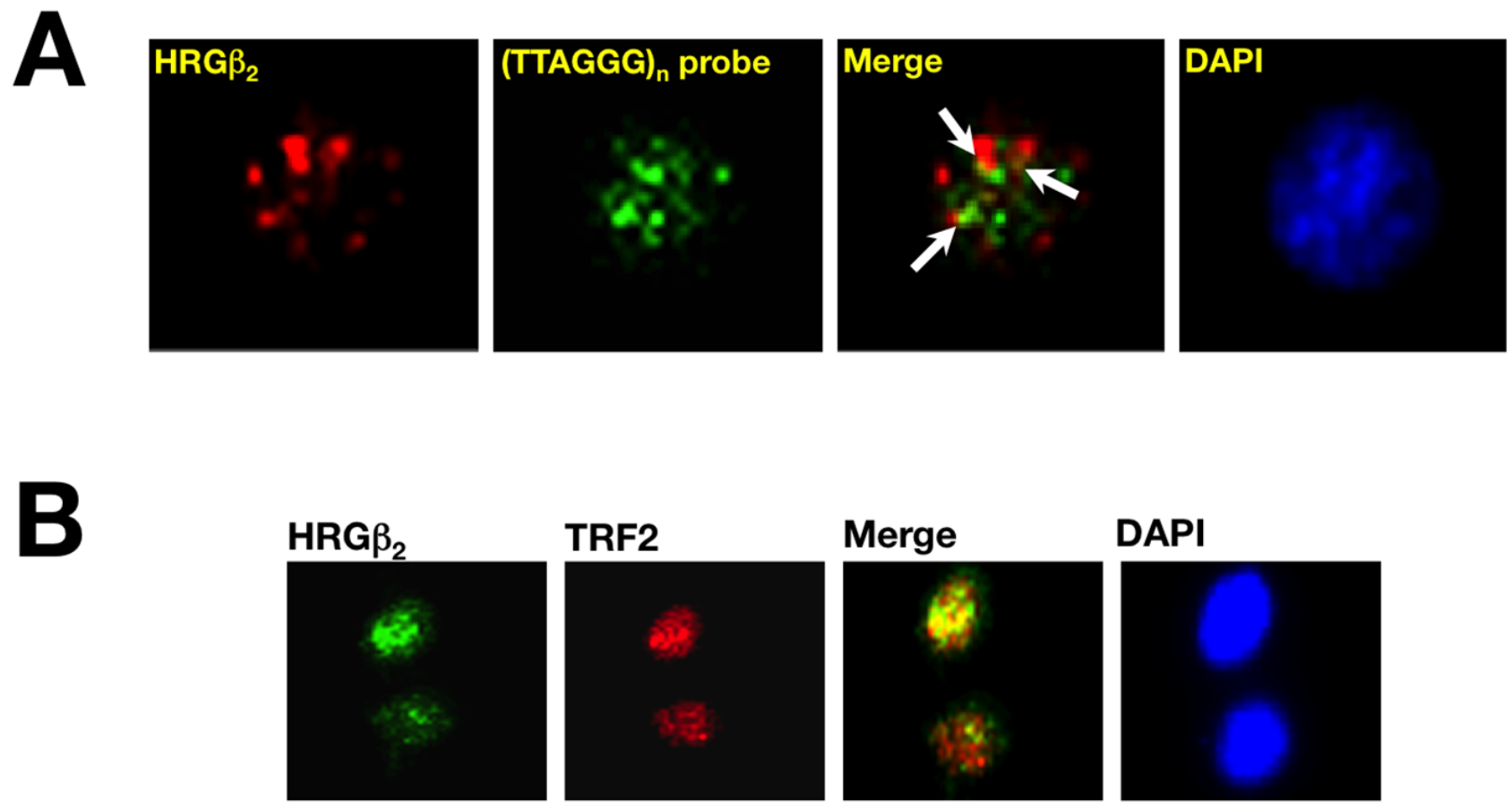

DAPI
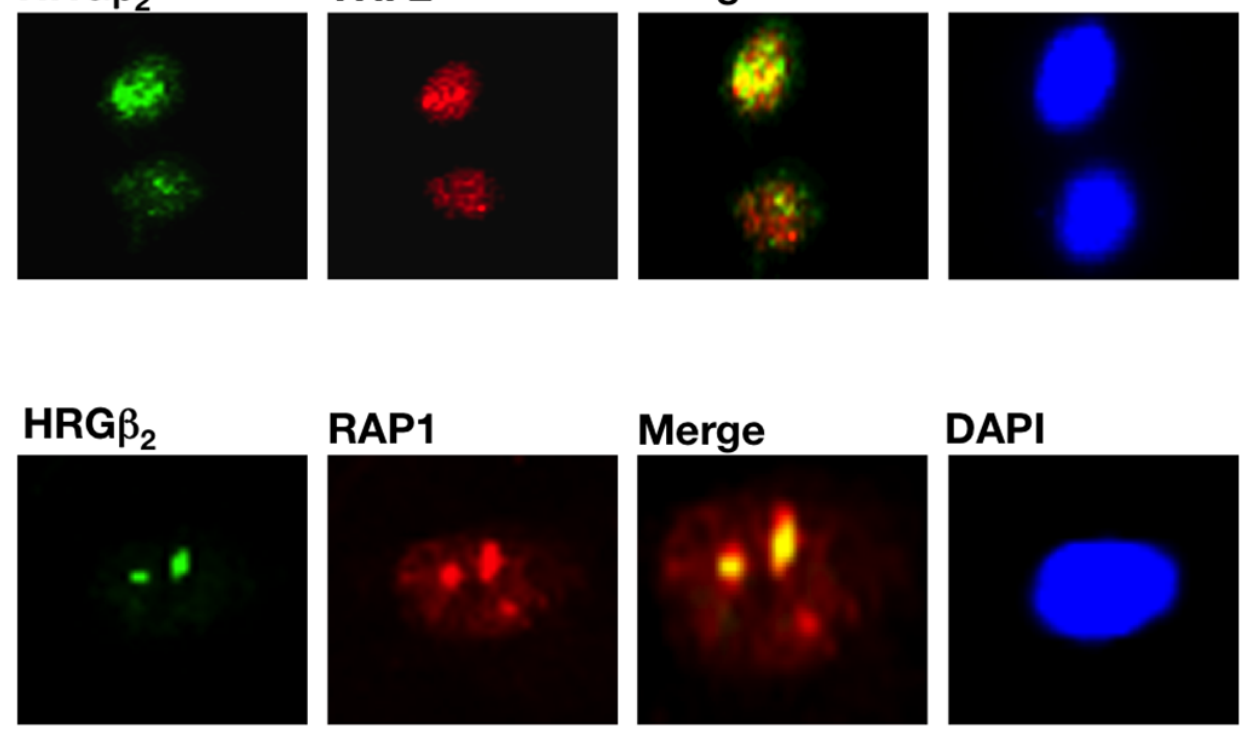

Figure 5: Telomeric localization of HRGß2 in human cancer cells. A. Subnuclear localization of HRG $\beta_{2}$ and its relationship with telomeric loci. A431 cells naturally overexpressing HRG $\beta_{2}$ were permeabilized twice and sequentially stained with an antibody against $\mathrm{HRG}_{2}$ (red) and the fluorescein-conjugated telomere-specific peptide nucleic acid (PNA) probe (green). DAPI was used to visualize nuclear DNA (blue). Merged images reveal partial co-localization of endogenous HRG $\beta_{2}$ and telomeres (yellow). B. Representative immunofluorescent images of A431 cells co-stained for endogenous HRG $\beta_{2}$ (green) using anti-TRF2 or anti-RAP1 (red) antibodies is shown $(n=3)$. Merged images, including DAPI staining of DNA, reveal a prominent co-localization (yellow) of endogenous HRG $\beta_{2}$ with TRF2 and RAP1. 
with anti-TRF2 and anti-RAP1 antibodies demonstrated that the speckled distribution pattern of endogenous HRG $\beta 2$ was found to significantly co-localize with native TRF2 and RAP1 (Figure 5). Equivalent results were observed in MDA-MB-231, Hs578T and MCF-7/HRG cells (data not shown).

\section{DISCUSSION}

We here present the first evidence that HRG $\beta 2$, a member of the HRG family of growth factors, is a novel regulator of telomere length in human cells. Our findings clearly show that HRG $\beta 2$ might negatively regulate telomere length by determining the ability of the telomerebinding proteins TRF2 and RAP1 to stably localize at chromosome ends.

Because telomere length in a cell population is determined by several factors including the activity of telomerase, the rate of telomere shortening, and the levels of telomere length controlling factors, we evaluated whether HRG $\beta 2$-induced changes in each of these parameters might explain the ability of HRG $\beta 2$ to reset telomere length to a new equilibrium. Using the classical PCR-based TRAP assay, we failed to detect any significant change in telomerase activity in response to changes in HRG $\beta 2$ expression. We therefore speculated that HRG $\beta 2$ induced changes in telomere length, as observed in TRF assays, might be due to changes in telomere-binding proteins, which are essential to preserve functional telomeres. The TTAGGG repeats of human telomeric DNA recruit telomere specific proteins, among them the classical telomere repeat binding proteins TRF1 and TRF2 [26-31]. These proteins are known to act in cis to repress telomere elongation. Whereas telomerase itself seems to be the target of TRF1-driven regulation of telomere length, TRF2 targeting and telomerase inhibition have been shown to induce additive effects on telomere length, thus suggesting that TRF2 can exclusively activate a telomeric degradation pathway. Accordingly, overexpression of full-length TRF2 leads to an increased rate of telomere shortening. TRF1 and TRF2, together with TRF1- and TRF2-interacting ankyrin-related ADP-ribose polymerase (Tankyrase) as well as TRF1-interacting nuclear protein 2 (TIN2), reorganize the linear chromosome end into a higher order structure known as the T-loop, a protected structure that hides the very end of the chromosome [30, 31, 39-45]. The telomere regulator, RAP1, was identified as a protein that negatively regulates telomere length by specifically interacting with TRF2 while functioning as a protein adaptor that brings different factors into the telomeric complex [32-35]. Thus, whereas the C-terminal domain of RAP1 (RCT) functions to interact with TRF2 and tethers RAP1 to telomeres, the N-terminal BRCT, Myb and linked domains of RAP1 have been suggested to recruit one or more protein factors, which together are required for the actual execution of the negative control of telomere length $[33,34]$.

What are the negative regulators recruited by the TRF1-RAP1 complex at chromosome ends? TRF2 and RAP1 have been shown to associate with proteins that play important roles in DSB repair, including components of the MRE11 complex (MRE11, RAD50, and NSB1) $[34,46]$. TRF2/RAP1-dependent telomere maintenance is influenced also by components of the DNA damage response pathway including $\mathrm{Ku} 70 / \mathrm{Ku} 80$ and PARP1 [47-50]. Our current findings strongly suggest that HRG $\beta 2$ might play a previously-unrecognized role in stabilizing the TRF2/RAP1 complex at chromosome ends which, in turn, might account for HRG $\beta 2$ 's ability to regulate telomere length maintenance in human cancer cells. While no significant changes were found in the expression of telomere-associated proteins, such as TRF1, TIN2, Tankyrase and $\mathrm{Ku} 70 / \mathrm{Ku} 80$, in response to changes in HRG $\beta 2$ expression (Figure 3, and data not shown), HRG $\beta 2$ overexpression induced a marked up-regulation of TRF2 and RAP1 and, in parallel, promoted telomere shortening. Moreover, knockdown of endogenous HRG $\beta 2$, either by stably expressing an antisense HRG $\beta 2$ cDNA or transfection with an HRG $\beta 2$-targeted siRNA, significantly diminished the abundance of TRF2 and RAP1, reduced the telomeric signals of these factors, and concomitantly promoted telomere lengthening. Although the precise mechanism responsible for the HRG $\beta 2$ driven regulation of native TRF2 and RAP1 remains to be elucidated, it is reasonable to postulate that altered post-translational modifications and, most likely, proteinprotein interactions, might underlie the ability of HRG $\beta 2$ to regulate the TRF2/RAP1 complex. Consistent with this notion, HRG $\beta 2$ significantly co-localized with TRF2 and RAP1 at the telomere complex (Figure 5), while coimmunoprecipitation assays revealed that HRG $\beta 2$ could directly interact with TRF2 (unpublished observations).

Short telomeres have a dual role in carcinogenesis since they could potentially lead to both cancer protection and cancer promotion $[51,52]$. Whereas telomere attrition due to the absence of telomerase activity (for instance, Terc or Tert knock-out mice) has been shown to suppress tumor growth [52-54], short telomeres have been described to generate chromosome instability, which in turn may lead to an increased risk of developing several cancers [55, 56]. Significant telomere shortening is prevalent in preinvasive breast lesions (e.g., ductal carcinoma in situ) as well as in focal areas of histologically-normal epithelium, where breast carcinoma is thought to arise [57, 58]. Moreover, reduced telomere DNA content correlates with genomic instability and metastasis in invasive breast carcinomas $[59,60]$. Consequently, telomere shortening has become a strong candidate as a cause of structural chromosome defects contributing to BC development and progression. Our findings are compatible with an HRG-regulated and TRF2/RAP1-dependent maintenance of telomere homeostasis, which depends on the action 
of telomerase at telomeres [61]. Interference with endogenous HRG $\beta 2$ might prevent the TRF2/RAP1 complex from sequestering telomere ends, thus enabling access to telomerase and resulting in extended telomeres. Conversely, HRG $\beta 2$ overexpression would promote the up-regulation and stabilization of the TRF2/RAP1 complex at chromosome ends, thus impeding telomerase access and resulting in shortened telomeres. It could be argued that short telomeres should trigger a DNAdamaging response (DDR), which, if not abrogated, could act as a tumor suppressor mechanism. This short telomeretriggered anti-cancer mechanism, however, can only occur in telomerase-deficient cells as previously demonstrated in the telomerase-deficient mouse model, which is resistant to carcinogenic treatments [53]. The cancer cell models used in this study are wild-type for telomerase genes and therefore are able to elongate short telomeres, thus ensuring continuous cell division.

According to the "protein-counting" model [2831, 61], HRG 32 -promoted very short telomeres might not bind sufficient amounts of TRF2 to create a "closed state" at the telomere [28-31, 61, 62]. At this stage, telomere elongation would again take place, preventing a complete loss of the telomeric DNA and resulting in the stabilization of the telomeres at a shorter length in HRG $\beta 2$ overexpressing cancer cells. The cancer promoting actions of HRG $\beta 2$ could therefore depend on its ability to trigger and maintain telomere shortening in a TRF2-dependent manner. Consistent with this concept, short telomeres produced by TRF2 overexpression have been shown to correlate with promotion of tumorigenesis $[55,56]$. Furthermore, an increased chromosomal instability due to elevated TRF2 can promote tumorigenesis in the presence of normal levels of telomerase $[55,56]$. Not surprisingly, TRF2 overexpression can be found in a high percentage of human basal cell carcinomas as well as in other types of human cancer including breast tumors, lung carcinomas, gastric carcinomas and liver hepatocarcinomas [6365]. TRF 2 overexpression in human hepatocarcinomas correlates with progressive telomere shortening, further suggesting a key role for TRF2 in linking telomere length and cancer progression [65]. Increased TRF2 expression leads to increased chromosomal instability due to telomere uncapping resulting from a critical telomere shortening and a defective nucleotide excision repair (NER) pathway [56]. We acknowledge that our study did not evaluate whether, in the setting of abrogate DNA damage checkpoints, HRG $\beta 2$-induced shorter telomeres concomitantly increased chromosomal aberrations due to end-to-end chromosomal fusions and subsequent breakage and rearrangement in cancer cells. Although further studies should elucidate how HRG $\beta 2$ impacts telomererelated chromosomal instability and DDR signaling, it is worthwhile to note that HRG $\beta 2$ overexpression dramatically increases the sensitivity of human cancer cells to DNA damaging agents such as doxorubicin and etopoxide $[6,12,13]$, thus recapitulating the increased sensitivity to DSB inducers and ionizing radiations promoted by short telomeres [20, 21, 36, 37, 66].

In summary, our data establish for the first time a functional link between HRG $\beta 2$ and telomere length maintenance through the unexpected ability of HRG $\beta 2$ to specifically regulate and interact with telomeres in human cancer cells. Since little is known about the factors involved in the regulation or in the recruitment of telomere-binding proteins to telomeres during normal development and in pathological conditions, our current findings demonstrating how the nuclear function of HRG unexpectedly involves the alteration of telomere homeostasis via TRF2 and RAP1, adds a further tier of complexity to the regulatory mechanisms of telomere length and function during tumor initiation and metastasis.

\section{MATERIALS AND METHODS}

\section{Materials}

Primary antibodies against TRF2 (IMG-124), TRF1 (IMG-283) and RAP1 (IMG-272) were purchased from Imgenex (San Diego, CA). The primary rabbit polyclonal anti-HRG $\beta_{2}$ antibody (C-20; sc-348) was purchased from Santa Cruz Biotech. (Santa Cruz, CA). Recombinant HRG was purchased from Lab Vision Corporation (Fremont, CA).

\section{Cell lines and culture conditions}

MCF-7, MDA-MB-231 and Hs578T human BC cells and A-431 human epidermoid carcinoma cells were obtained from the American Type Culture Collection (ATCC). Cells were routinely maintained in phenol red-containing improved MEM (IMEM, Biosource International, Camarillo, CA) supplemented with 5\% $(\mathrm{v} / \mathrm{v})$ fetal bovine serum and $2 \mathrm{mmol} / \mathrm{L}$ L-glutamine at 37 ${ }^{\circ} \mathrm{C}$ in a humidified atmosphere of $95 \%$ air and $5 \% \mathrm{CO}_{2}$, unless otherwise specified. $\mathrm{HRG} \beta_{2}$-overexpressing T6 and T8 clones were engineered by transfecting MCF-7 cells either with an empty eukaryotic expression vector $\mathrm{pRC/}$ CMV (MCF-7/V cells) or with pRC/CMV containing the full-length cDNA of human $\mathrm{HRG} \beta_{2}$ as described [9]. HRG $\beta_{2}$-overexpressing MCF-7/T6 and MCF-7/T8 clones were grown as indicated above, except that $450 \mu \mathrm{g} / \mathrm{ml}$ G418 (Geneticin, Sigma-Chemicals, St. Louis, MO) was added to the culture medium. MDA-MB-231 and Hs578T antisense (AS)-HRG $\beta_{2}$ clones were generated as described [11]. Briefly, the $\mathrm{HRG} \beta_{2}$ cDNA (amino acids 1-426) was cloned in an antisense direction into $\mathrm{pRC} / \mathrm{CMV}$ and subsequently transfected into MDA-MB-231 and Hs578T cells. MDA-MB-231/AS-V and Hs578T/AS-V cells were transfected with empty $\mathrm{pRC} / \mathrm{CMV}$, whereas MDA- 
MB-231 AS-HRG and Hs578T AS-HRG $\beta_{2}$ cells were transfected with $\mathrm{pRC} / \mathrm{CMV}$ containing the antisenseHRG $\beta_{2}$. Selected AS-HRG $\beta_{2}$ clones and non-selected ASHRG $\beta{ }_{2}$ pools were maintained as described above with the addition of $200 \mu \mathrm{g} / \mathrm{mL} \mathrm{G} 418$ in the medium.

\section{DNA constructs and retroviral infection}

The PCR product generated using the HRG $\beta_{2}$ cDNA accession number 183996 as a template was cloned into the retroviral expression vector $\mathrm{pBABE}-\mathrm{Puro}$ using $\mathrm{Bam \textrm {HI }}$ and $E c o$ RI restriction sites. Full-length $\mathrm{HRG} \beta_{2}$ cDNA in pBABE was transfected into a high efficiency transient packaging system using FuGENE transfection reagent (Roche, Indianapolis, IN). Retrovirus-containing medium collected after $48 \mathrm{~h}$ was used to infect MCF-7 cells for $24 \mathrm{~h}$ in the presence of Polybrene (Sigma-Chemicals). Infected MCF-7 cells were grown for an additional $24 \mathrm{~h}$ in standard medium and stable cell lines (MCF-7/pBABE and MCF-7/HRG) were selected and expanded in the presence of $2.5 \mu \mathrm{g} / \mathrm{mL}$ puromycin for at least two weeks. HRG $\beta_{2}$ expression was assessed by RT-PCR using the Gene Amp Kit (Promega Corporation, Madison WI).

\section{Analysis of telomerase activity (TRAP assay)}

Telomerase activity was determined by using the highly sensitive one buffer, two enzymes in vitro system TRAP $_{\text {EZE }}^{\circledR}$ Telomerase Detection Kit (Intergen, Purchase, NY) $[36,37]$. In the first step of the reaction, telomerase adds a number of telomeric repeats (GGTTAG) onto the 3' end of a substrate oligonucleotide (TS). In the second step, the extended products are amplified by PCR using the TS and RP (reverse) primers, thus generating a ladder of products with 6 base increments starting at 50 nucleotides. Additionally, each reaction mixture contains a primer (K1) and a template (TSK1) for amplification of a 36-bp internal standard. In our experiments, sub-confluent cells were collected by trypsinization and counted using the Coulter counter. Lysates from $10^{3}$ cells were incubated in a telomerase reaction buffer at $30^{\circ} \mathrm{C}$ for $30 \mathrm{~min}$, followed by 33 PCR cycles $\left(94^{\circ} \mathrm{C} / 30\right.$ seconds, $59^{\circ} \mathrm{C} / 30$ seconds). The PCR products were resolved on a $12 \%$ polyacrylamide gel, visualized with SYBR Green I Nucleic Acid Gel Stain, and scanned directly with a Molecular Dynamics Storm System (Molecular Dynamics). Relative telomerase activities were obtained after comparison with the signal from parental cells, which were always measured on the same gel. Between two and five parallel measurements were performed from each clone.

\section{Analysis of terminal restriction fragment (TRF) length}

Cells from a sub-confluent 100-mm diameter culture dish were harvested by trypsinization, washed in cold PBS, collected by centrifugation for $5 \mathrm{~min}$ at 1,500 $x \mathrm{rpm}$, and counted using the Coulter counter. Cell pellets were frozen at $-80{ }^{\circ} \mathrm{C}$ until analysis. Genomic DNA was isolated from cell pellets (approximately $5 \times 10^{6}$ cells for each clone) using a DNA extraction kit (Qiagen, Santa Clarita, CA) with inclusion of an RNase A digestion step, and quantitated with a spectrophotometer. Protein-free DNA was cleaved with Hinfl and RsaI restriction enzymes (Gibco/BRL), extracted once with phenol/chloroform/ isoamyl alcohol, ethanol precipitated, and resuspended in Tris-EDTA to generate the TRF. A portion of DNA was subjected to electrophoresis in a $0.5 \%$ agarose gel in $1 \mathrm{X}$ Tris-borate EDTA (TBE) buffer at $2 \mathrm{~V} \mathrm{~cm}^{-1}$ for $17 \mathrm{~h}$. The gel was subsequently dried at $60^{\circ} \mathrm{C}$ for $2 \mathrm{~h}$, denatured for $30-60 \mathrm{~min}$ in $0.5 \mathrm{~mol} / \mathrm{L} \mathrm{NaOH}$ and $1.5 \mathrm{~mol} / \mathrm{L} \mathrm{NaCl}$, and neutralized for 30-60 min in $1 \mathrm{~mol} / \mathrm{L}$ Tris-HCl, $\mathrm{pH} 8.0$ and $1.5 \mathrm{~mol} / \mathrm{L} \mathrm{NaCl}$. The dried gel was then subjected to in-gel hybridization with a $\left[\gamma^{3}{ }^{32} \mathrm{P}\right]$-ATP 5 ' end-labeled telomeric oligonucleotide probe $\left[\gamma^{-32}{ }^{32}-(\mathrm{TTAGG})_{3}\right][36,37]$.

\section{Calculation of mean TRF length}

Although an estimate of the TRF length can be obtained by visually comparing the size of the signal smear with molecular weight markers, we calculated the TRF length for each sample by integrating the signal intensity above background over the entire TRF distribution as a function of TRF length using the formula:

\section{$\mathrm{L}=\sum(\mathrm{ODi} \cdot \mathrm{Li}) / \sum(\mathrm{ODi})$ Equation 1}

Where ODi and Li were the signal intensity and TRF length, respectively, at position i on the gel image. This method takes into account the greater intensity of signals from larger fragments. The amount of telomeric DNA was calculated by integrating the volume of each smear using a Phosphorimager (Amersham Biosciences) and Image-QuaNT software (Molecular Dynamics). Briefly, the scanned image was divided into a grid consisting of $X$ columns and multiple rows where $X$ denotes the number of samples. The rows were positioned to cover the entire vertical length of the image. The vertical size of grid boxes was arbitrary, but it was small enough such that many boxes overlaid a signal smear. The background was calculated using two rows above and two rows below each signal smear. The background OD was averaged and then subtracted from the OD of each grid box to give the signal due to TRFs at that position. For each sample, OD and L were computed for each grid box, where OD was the total signal intensity within a grid box and L was the distance (in $\mathrm{cm}$ ) at the mid-point of the grid box. Mean TRF length was then calculated using Equation 1 and values 
were reported as the average of at least two independent Southern blots [36, 37].

\section{Calculation of population doublings (PD)}

The total number of cells harvested was calculated at every subculture and the number of accumulated PDs per passage was determined using the equation $\mathrm{PD}=$ $(A / B) / \log 2$, where $A$ is the number of harvested cells and $B$ the number of plated cells, not corrected for plating efficiency $[36,37]$.

\section{Western blot analyses}

Harvested cells were washed twice with PBS and then lysed in buffer $[20 \mathrm{mmol} / \mathrm{L}$ Tris $(\mathrm{pH} 7.5), 150$ $\mathrm{mmol} / \mathrm{L} \mathrm{NaCl}, 1 \mathrm{mmol} / \mathrm{L}$ EDTA, $1 \mathrm{mmol} / \mathrm{L}$ EGTA, 1\% Triton X-100, $2.5 \mathrm{mmol} / \mathrm{L}$ sodium pyrophosphate, 1 $\mathrm{mmol} / \mathrm{L} \beta$-glycerolphosphate, $1 \mathrm{mmol} / \mathrm{L} \mathrm{Na}_{3} \mathrm{VO}_{4}, 1 \mu \mathrm{g} /$ $\mathrm{mL}$ leupeptin, $1 \mathrm{mmol} / \mathrm{L}$ phenylmethylsulfonylfluoride] for $30 \mathrm{~min}$ on ice. The lysates were cleared by centrifugation in an eppendorf microcentrifuge (15 min at $14,000 \times \mathrm{rpm}, 4^{\circ} \mathrm{C}$ ). Protein content was determined against a standardized control using the Pierce Protein Assay Kit (Rockford, IL). Equal amounts of protein were resuspended in 5X Laemmli sample buffer for $10 \mathrm{~min}$ at 70 ${ }^{\circ} \mathrm{C}$, subjected to electrophoresis on $10 \%$ SDS-PAGE gels and transferred to nitrocellulose membranes. Nonspecific binding was minimized by blocking membranes for 1 $\mathrm{hr}$ at room temperature (RT) with TBS-T [25 mmol/L Tris- $\mathrm{HCl}, 150 \mathrm{mmol} / \mathrm{L} \mathrm{NaCl}(\mathrm{pH} \mathrm{7.5)}$, and 0.05\% Tween $20]$ containing $5 \%(\mathrm{w} / \mathrm{v})$ nonfat dry milk. Membranes were then washed in TBS-T and incubated with primary antibodies for $2 \mathrm{hr}$ at RT in TBS-T containing 1\% (w/v) nonfat dry milk. After a further in TBS-T, anti-rabbit or anti-mouse horseradish peroxidase-conjugated secondary antibodies (Jackson ImmunoResearch Labs, West Grove, PA) in TBS-T were added for $1 \mathrm{hr}$ and immunoreactive bands were detected by enhanced chemiluminescence reagent (Pierce, Rockford, IL). Blots were re-probed with an antibody for $\beta$-actin to control for protein loading and transfer. The results were scanned and intensity bands were quantified using NIH Image 1.62 software.

\section{Indirect immunofluorescence (IF)}

Cells grown on coverslips were fixed/permeabilized with $0.2 \%$ Triton X-100/2\% paraformaldehyde and permeabilized again in $100 \%$ methanol for $10 \mathrm{~min}$ at $-20^{\circ} \mathrm{C}$. Coverslips were subsequently blocked for $30 \mathrm{~min}$ at $37^{\circ} \mathrm{C}$ in $5 \%$ BSA in PBS and incubated with primary and fluorescent-conjugated secondary antibodies for $1 \mathrm{~h}$ each at RT. DNA was stained with diamidino-2-phenylindole (DAPI). Stained cells were observed and analyzed using a Nikon Eclipse E800 microscope equipped for epifluorescence.

\section{IF staining combined with telomere fluorescence in situ hybridization (FISH)}

IF combined with FISH was performed essentially as described by Ohki \& Ishikawa [38] with some modifications. Briefly, cells grown on cover-slides were fixed for $15 \mathrm{~min}$ in PBS containing 2\% paraformaldehyde and then permeabilized in PBS containing $0.2 \%$ Triton X-100 for $5 \mathrm{~min}$, washed with PBS, and post-fixed for $20 \mathrm{~min}$ in $100 \%$ methanol at $-20^{\circ} \mathrm{C}$. After two washes with PBS, cells were blocked in PBS containing $5 \mathrm{mg} /$ $\mathrm{mL} \mathrm{BSA}$ and $20 \mathrm{mmol} / \mathrm{L}$ glycine for $30 \mathrm{~min}$. Cells were stained with anti-HRG $\beta_{2}$ antibody (1:100 dilution; C-20, Santa Cruz Biotech.) followed by TRITC-conjugated antirabbit IgG antibody, both of which were diluted with PBS containing $5 \mathrm{mg} / \mathrm{mL}$ BSA. Then, the cells were fixed with $4 \%$ paraformaldehyde for $7 \mathrm{~min}$ and incubated in PBS containing $5 \mathrm{mg} / \mathrm{ml} \mathrm{BSA}$ and $20 \mathrm{mmol} / \mathrm{L}$ glycine for 30 min, and subjected to telomere FISH using the Telomere PNA Kit (DakoCytomation, Denmark) following the manufacturer's instructions except that cells were not pre-treated with proteolytic enzyme solution. DNA was stained with DAPI. Stained cells were observed and analyzed as above.

\section{ACKNOWLEDGMENTS}

Work in the corresponding authors' labs was supported by Department of Defense award W81XWH-06-1-0703, the National Institute of Health/ National Cancer Institute award R01-CA118975 and by the Department of Energy under Contract No. DEAC03-76SF00098 to Ruth Lupu and by grants from the Ministerio de Ciencia e Innovación (Grant SAF201238914), Plan Nacional de I+D+I, Spain and the Agència de Gestió d'Ajuts Universitaris i de Recerca (AGAUR) (Grant 2014 SGR229), Departament d'Economia I Coneixement, Catalonia, Spain to Javier A. Menendez.

\section{CONFLICTS OF INTEREST}

There is no conflict of interest.

\section{REFERENCES}

1. Plowman GD, Green JM, Culouscou JM, Carlton GW, Rothwell VM and Buckley S. Heregulin induces tyrosine phosphorylation of HER4/p180erbB4. Nature. 1993; 366:473-475.

2. Carraway KL 3rd, Sliwkowski MX, Akita R, Platko JV, Guy PM, Nuijens A, Diamonti AJ, Vandlen RL, Cantley 
LC and Cerione RA. The erbB3 gene product is a receptor for heregulin. J Biol Chem. 1994; 269:14303-14306.

3. Lupu R, Colomer R, Zugmaier G, Sarup J, Shepard M, Slamon D and Lippman ME. Direct interaction of a ligand for the erbB2 oncogene product with the EGF receptor and p185erbB2. Science. 1990; 249:1552-1555.

4. Holmes WE, Sliwkowski MX, Akita RW, Henzel WJ, Lee J, Park JW, Yansura D, Abadi N, Raab H, Lewis GD, et al. Identification of heregulin, a specific activator of p185erbB2. Science. 1992; 256:1205-1210.

5. Lupu R, Colomer R, Kannan B and Lippman ME. Characterization of a growth factor that binds exclusively to the erbB-2 receptor and induces cellular responses. Proc Natl Acad Sci USA. 1992; 89:2287-2291.

6. Lupu R, Cardillo M, Cho C, Harris L, Hijazi M, Perez C, Rosenberg K, Yang D and Tang C. The significance of heregulin in breast cancer tumor progression and drug resistance. Breast Cancer Res Treat. 1996; 38:57-66.

7. Alimandi M, Romano A, Curia MC, Muraro R, Fedi P, Aaronson SA, Di Fiore PP and Kraus MH. Cooperative signaling of ErbB3 and ErbB2 in neoplastic transformation and human mammary carcinomas. Oncogene. 1995; 10:1813-1821.

8. Lewis GD, Lofgren JA, McMurtrey AE, Nuijens A, Fendly BM, Bauer KD and Sliwkowski MX. Growth regulation of human breast and ovarian tumor cells by heregulin: Evidence for the requirement of ErbB2 as a critical component in mediating heregulin responsiveness. Cancer Res. 1996; 56:1457-1465.

9. Tang CK, Perez C, Grunt T, Waibel C, Cho C and Lupu $\mathrm{R}$. Involvement of heregulin-beta2 in the acquisition of the hormone-independent phenotype of breast cancer cells. Cancer Res. 1996; 56:3350-3358.

10. Atlas E, Cardillo M, Mehmi I, Zahedkargaran H, Tang C and Lupu R. Heregulin is sufficient for the promotion of tumorigenicity and metastasis of breast cancer cells in vivo. Mol Cancer Res. 2003; 1:165-175.

11. Tsai MS, Shamon-Taylor LA, Mehmi I, Tang CK and Lupu R. Blockage of heregulin expression inhibits tumorigenicity and metastasis of breast cancer. Oncogene. 2003; 22:761768.

12. Harris LN, Yang L, Tang C, Yang D, Lupu R. Induction of sensitivity to doxorubicin and etoposide by transfection of MCF-7 breast cancer cells with heregulin beta-2. Clin Cancer Res 1998; 4:1005-1012.

13. Atlas E, Bojanowski K, Mehmi I and Lupu R. A deletion mutant of heregulin increases the sensitivity of breast cancer cells to chemotherapy without promoting tumorigenicity. Oncogene. 2003; 22:3441-3451.

14. Menendez JA, Mehmi I and Lupu R. Heregulin-triggered Her-2/neu signaling enhances nuclear accumulation of p21WAF1/CIP1 and protects breast cancer cells from cisplatin-induced genotoxic damage. Int J Oncol. 2005; 26:649-659.
15. Alaoui-Jamali MA, Paterson J, Al Moustafa AE and Yen L. The role of ErbB-2 tyrosine kinase receptor in cellular intrinsic chemoresistance: mechanisms and implications. Biochem Cell Biol. 1997; 75:315-325.

16. Harris LN, Yang L, Liotcheva V, Pauli S, Iglehart JD, Colvin OM and Hsieh TS. Induction of topoisomerase II activity after ErbB2 activation is associated with a differential response to breast cancer chemotherapy. Clin Cancer Res. 2001; 7:1497-1504.

17. Saldanha SN, Andrews LG and Tollefsbol TO. Assessment of telomere length and factors that contribute to its stability. Eur J Biochem. 2003; 270:389-403.

18. Campisi J, Kim SH, Lim CS and Rubio M. Cellular senescence, cancer and aging: the telomere connection. Exp Gerontol. 2001; 36:1619-1637.

19. Karlseder J, Smogorzewska A and de Lange T. Senescence induced by altered telomere state, not telomere loss. Science. 2002; 295:2446-2449.

20. Lee KH, Rudolph KL, Ju YJ, Greenberg RA, Cannizzaro L, Chin L, Weiler SR and DePinho RA. Telomere dysfunction alters the chemotherapeutic profile of transformed cells. Proc Natl Acad Sci USA. 2001; 98:3381-3386.

21. Elmore LW, Rehder CW, Di X, McChesney PA, JacksonCook CK, Gewirtz DA and Holt SE. Adriamycin-induced senescence in breast tumor cells involves functional p53 and telomere dysfunction. J Biol Chem. 2002; 277:3550935515 .

22. Ishibashi $\mathrm{T}$ and Lippard SJ. Telomere loss in cells treated with cisplatin. Proc Natl Acad Sci USA. 1998; 95:42194223.

23. Ramirez R, Carracedo J, Jimenez R, Canela A, Herrera E, Aljama $\mathrm{P}$ and Blasco MA. Massive telomere loss is an early event of DNA damage-induced apoptosis. J Biol Chem. 2003; 278:836-842.

24. Li W, Park JW, Nuijens A, Sliwkowski MX and Keller GA. Heregulin is rapidly translocated to the nucleus and its transport is correlated with c-myc induction in breast cancer cells. Oncogene 1996; 12:2473-2477.

25. Breuleux M, Schoumacher F, Rehn D, Kung W, Mueller $\mathrm{H}$ and Eppenberger U. Heregulins implicated in cellular functions other than receptor activation. Mol Cancer Res. 2006; 4:27-37.

26. Broccoli D, Smogorzewska A, Chong L and de Lange T. Human telomeres contain two distinct Myb-related proteins, TRF1 and TRF2. Nat Genet. 1997; 17:231-235.

27. van Steensel B, Smogorzewska A and de Lange T. TRF2 protects human telomeres from end-to-end fusions. Cell. 1998; 92:401-413.

28. Smogorzewska A, van Steensel B, Bianchi A, Oelmann S, Schaefer MR, Schnapp G and de Lange T. Control of human telomere length by TRF1 and TRF2. Mol Cell Biol. 2000; 20:1659-1668.

29. Ancelin K, Brun C and Gilson E. Role of the telomeric DNA-binding protein TRF2 in the stability of human 
chromosome ends. Bioessays. 1998; 20:879-883.

30. de Lange T. Protection of mammalian telomeres. Oncogene. 2002; 21:532-540.

31. Karlseder J. Telomere repeat binding factors: keeping the ends in check. Cancer Lett. 2003; 194:189-197.

32. Li B, Oestreich $\mathrm{S}$ and de Lange T. Identification of human Rap1: implications for telomere evolution. Cell. 2000, 101:471-483.

33. Li B and de Lange T. Rap1 affects the length and heterogeneity of human telomeres. Mol Biol Cell. 2003, 14:5060-5068.

34. O'Connor MS, Safari A, Liu D, Qin J and Songyang Z. The human Rap1 protein complex and modulation of telomere length. J Biol Chem. 2004, 279:28585-28591.

35. Liu D, O'Connor MS and Songyang Z. Telosome, a mammalian telomere-associated complex formed by multiple telomeric proteins. J Biol Chem. 2004; 279: 51338-51342.

36. Rubio M, Kim SH, Campisi J. Reversible manipulation of telomerase expression and telomere length. Implications for the ionizing radiation response and replicative senescence of human cells. J Biol Chem. 2002; 277: 28609-28617.

37. Rubio MA, Davalos AR and Campisi J. Telomere length mediates the effects of telomerase on the cellular response to genotoxic stress. Exp Cell Res 2004; 298:17-27.

38. Ohki R and Ishikawa F. Telomere-bound TRF1 and TRF2 stall the replication fork at telomeric repeats. Nucleic Acids Res. 2004; 32:1627-1637.

39. Griffith JD, Comeau L, Rosenfield S, Stansel RM, Bianchi A, Moss $\mathrm{H}$ and de Lange T. Mammalian telomeres end in a large duplex loop. Cell. 1999; 97:503-514.

40. de Lange T. Shelterin: the protein complex that shapes and safeguards human telomeres. Genes Dev. 2005; 19:21002110 .

41. LeBel C and Wellinger RJ. Telomeres: what's new at your end? J Cell Sci. 2005; 118:2785-2788.

42. Kim SH, Kaminker P and Campisi J. TIN2, a new regulator of telomere length in human cells. Nat Genet. 1999, 23:405412.

43. Kim SH, Beausejour C, Davalos AR, Kaminker P, Heo SJ and Campisi J. TIN2 mediates functions of TRF2 at human telomeres. J Biol Chem. 2004; 279:43799-43804.

44. Smith S and de Lange T. Tankyrase promotes telomere elongation in human cells. Curr Biol. 2000; 10:1299-1302.

45. Smith S, Giriat I, Schmitt A and de Lange T. Tankyrase, a poly(ADP-ribose) polymerase at human telomeres. Science. 1998, 282:1484-1487.

46. Zhu XD, Küster B, Mann M, Petrini JH and de Lange T. Cell-cycle-regulated association of RAD50/MRE11/ NBS1 with TRF2 and human telomeres. Nature Gen. 2000; 25:347-352.

47. Bianchi A and de Lange T. Ku binds telomeric DNA in vitro. J Biol Chem. 1999; 274:21223-21227.
48. Myung K, Ghosh G, Fattah FJ, Li G, Kim H, Dutia A, Pak E, Smith S and Hendrickson EA. Regulation of telomere length and suppression of genomic instability in human somatic cells by Ku86. Mol Cell Biol. 2004; 24:5050-5059.

49. Jaco I, Munoz P and Blasco MA. Role of human Ku86 in telomere length maintenance and telomere capping. Cancer Res. 2004; 64:7271-7278.

50. Gomez M, Wu J, Schreiber V, Dunlap J, Dantzer F, Wang Y and Liu Y. PARP1 is a TRF2-associated poly(ADPribose)polymerase and protects eroded telomeres. Mol Biol Cell. 2006; 17:1686-1696.

51. Blasco MA and Hahn WC. Evolving view of telomerase and cancer. Trends Cell Biol. 2003; 13:289-294.

52. Blasco MA. Telomeres and human disease: cancer, aging and beyond. Nat Rev Genet. 2005; 6:611-622.

53. Gonzalez-Suarez E, Samper E, Flores JM and Blasco MA. Telomerase-deficient mice with short telomeres are resistant to skin tumorigenesis. Nat Genet. 2000; 26:114-117.

54. Samper E, Flores JM and Blasco MA. Restoration of telomerase activity rescues chromosomal instability and premature aging in Terc-/- mice with short telomeres. EMBO Reports 2001; 2:1-8.

55. Munoz P, Blanco R, Flores JM and Blasco MA. XPF nuclease-dependent telomere loss and increased DNA damage in mice overexpressing TRF2 result in premature aging and cancer. Nat Genet. 2005; 10:1063-1071.

56. Munoz P, Blanco R and Blasco MA. Role of the TRF2 telomeric protein in cancer and ageing. Cell Cycle. 2006; 5:718-721.

57. Meeker AK and Argani P. Telomere shortening occurs early during breast tumorigenesis: A cause of chromosome destabilization underlying malignant transformation? J Mammary Gland Biol Neoplasia. 2004; 9:285-296.

58. Chin K, de Solorzano CO, Knowles D, Jones A, Chou W, Rodriguez EG, Kuo WL, Ljung BM, Chew K, Myambo K, Miranda M, Krig S, Garbe J, Stampfer M, Yaswen P, Gray JW and Lockett SJ. In situ analyses of genome instability in breast cancer. Nat Genet. 2004; 36:984-988.

59. Griffith JK, Bryant JE, Fordyce CA, Gilliland FD, Joste NE and Moyzis RK. Reduced telomere DNA content is correlated with genomic instability and metastasis in invasive human breast carcinoma. Breast Cancer Res Treat. 1999; 54:59-64.

60. Meeker AK, Hicks JL, Gabrielson E, Strauss WM, De Marzo AM and Argani P. Telomere shortening occurs in subsets of normal breast epithelium as well as in situ and invasive carcinoma. Am J Pathol. 2004; 164:925-935.

61. Smogorzewska A and de Lange T. Regulation of telomerase by telomeric proteins. Annu Rev Biochem. 2004, 73: 177208.

62. Blackburn EH. Switching and signaling at the telomere. Cell. 2001; 106:661-673.

63. Nijjar T, Bassett E, Garbe J, Takenaka Y, Stampfer MR, Gilley and Yaswen P. Accumulation and altered 
localization of telomere-associated protein TRF2 in immortally transformed and tumor-derived human breast cells. Oncogene. 2005; 24:3369-3376.

64. Matsutani N, Yokozaki H, Tahara E, Tahara H, Kuniyasu H, Haruma K, Chayama K, Yasui W and Tahara E. Expression of telomeric repeat binding factor 1 and 2 and TRF1interacting nuclear protein 2 in human gastric carcinoma. Int J Oncol. 2001; 19:507-512.

65. Oh B-K, Kim Y-J, Parc C and Park YN. Up-regulation of telomere-binding proteins, TRF1, TRF2 and TIN2 is related to telomere shortening during human multistep hepatocarcinogenesis. Am J Pathol. 2005; 166:73-80.

66. Goytisolo FA, Samper E, Martín-Caballero J, Finnon P, Herrera E, Flores JM, Bouffler SD and Blasco MA. Short telomeres result in organismal hypersensitivity to ionizing radiation in mammals. J Exp Med. 2000; 192:1625-1636. 